\title{
MODELING OF SEDIMENT YIELD FOR MALAPRABHA SUB BASIN USING SWAT
}

\author{
Nagraj S. Patil ${ }^{1}$, Priyanka ${ }^{2}$ \\ ${ }^{1}$ Associate Professor, VTU PG Center, Belagavi, 590018, India \\ ${ }^{2} 2^{\text {nd }}$ year M. Tech, VTU PG Center, Belagavi, 590018, India
}

\begin{abstract}
Soil erosion is one of the most serious environmental problem since the fertile soil which is rich in nutrients gets removed. This erosion of soil reduces the capacity and life span of rivers and reservoirs. This has become severe problem which is a challenging management task for the water resource department. Thus soil resource need to be conserved for optimal land use for maintaining and improving soil productivity. Since mathematical models have great potential to support landuse planning with the goal of improving water and land quality. In this study, the Soil and Water Assessment Tool(SWAT) model having an interface with ArcView GIS software is used for estimation of sediment yield for Malaprabha sub basin. The model is calibrated and validated using observed runoff and sediment yield data. Calibration is done manually. By this study we come to know that the model with corresponding optimum set of parameters is able to predict water flow and sediment yield values, which might be beneficial for future planning and management in mitigating the problems of soil erosion and sedimentation.
\end{abstract}

Keywords: Soil Erosion, Sediment yield, SWAT, Malaprabha Sub basin $* * *$

\section{INTRODUCTION}

Sediment yield directs to the measure of quantity traded by a basin over a timeframe, which is likewise the sum that will enter a store situated at the downstream furthest reaches of the basin (Morris and Fan, 1998). The subject of residue yield modeling has pulled in the consideration of numerous researchers however absence of information, assets and broadly acknowledged strategies to anticipate/gauge sediments yields are a portion of the boundaries against this bearing of study (Summer et al., 1992; Shimelis et al., 2010).

Enhanced soil disintegration, which is created because of the anthropogenic intercession, is representing an extreme test to the profitability of area by the loss of productive soil and to the life of stores by the testimony of residue. The procedure of soil disintegration and sediments transport and affidavit are nonlinearly identified with the causal elements and are exceptionally variable both spatially and transiently (White et al., 2005). Checking of these procedures is entirely perplexing and costly. Modeling gives an option way to deal with valuation of sediments yield furthermore a superior comprehension of residue development andconveyance. As of late, a portion of the conspicuous models like the Universal Soil Loss Equation (USLE) and its adjustments like the Modified USLE (MUSLE) and the Revised USLE (RUSLE) are progressively being utilized (Prabhanjan et al., 2015).

The soil and water appraisal tool (SWAT) is a substantially based model, which has been utilized all through the world for hydrological modeling and sedimentation yield concentrates on, to speak to the spatial marvels (Kaur et al., 2003). A geographic Information system (GIS) has not just been utilized for association, stockpiling,procurement, and showcase of spatial information, additionally for undertakings like programmed watershed outline, adding spatial parameters, and incorporating different hydrological models.

In light of the above perceptions and different reports, it can be inferred that SWAT is one of the favorable models for overflow and sediments yield demonstrating. What's more, it has been well recognized that remote Sensing and GIS can be adequately used to exhibit the overflow and sediment yield from watersheds.

The main aim of the present study is to assess SWAT model performance and its applicability in prediction of monthly sediment yield.

\subsection{Problem Definition}

Malaprabha, a sub basin of Krishna basin in India. According to the 'State of the Environment Report 2003'. It states that, because of this decrease in storage capacity, it is leading to inadequate water supply and causing recurrent floods. As a result of this soil erosion, the storage capacity has reduced which leads to reduction in water spread area and availability of water. This siltation problem is higher especially in Krishna basin which includes Malaprabha basin. Hence this provides an opportunity to model and analyze the sediment yield in the study area.

\section{METHODOLOGY}

In India, Krishna river basin is the biggest basin covering parts of Karnataka, Andhra Pradesh and Maharashtra. The basin lies in the Deccan Plateau. The catchment area of 
Malaprabha lies amid $15^{\circ} 00^{\prime} \mathrm{N}$ and $16^{\circ} 12^{\prime} \mathrm{N}$ and $74^{\circ} 14^{\prime} \mathrm{E}$ and $76^{\circ} 14^{\prime}$ E. From Chorla Ghats which is a Western Ghats segment, the Malaprabha River starts. The river joins Krishna at Kapila Sangam at an altitude of around 488m streaming east and north-west. Malaprabha meets the Krishna River after it crosses a length of $306 \mathrm{~km}$ covering catchment area of 11,549 sq. km.Location of the study area is as demonstrated in below fig. 1 .
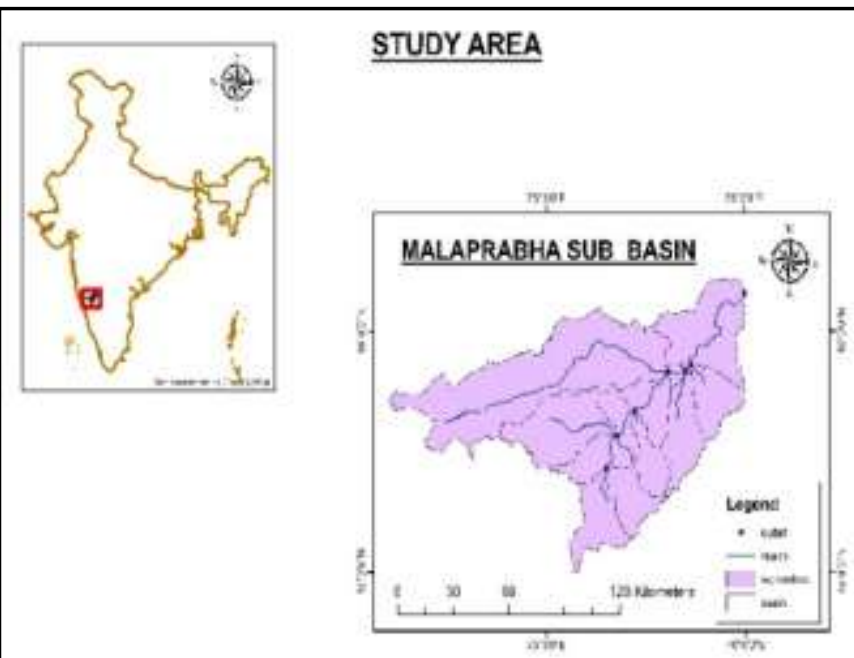

Fig. 1: Location of study area

\subsection{Data Required}

- DEM

- Topographic map

- Soil classes

- LULC map

- Weather data

\subsection{Methodology}

\subsubsection{Hydrological Modelling}

Hydrological models are the simplified mathematical demonstrations of a real hydrological system such as a river basin or a part of it. The main tools for hydrologist are the hydrological models used for different purposes such as water resource management, modeling of groundwater, watershed management for both urban and rural watersheds etc.

SWAT model was developed by the USDA Agricultural Research Service (ARS), to assess the impacts of land use practices on sediment yield, water quality and chemical yields over long period of time in vast watersheds having different kinds of soils and land use practices.

SWAT uses the Modified Universal Soil Loss Equation (MUSLE) for the sediment yield calculation. Which is given as:

$$
\begin{gathered}
\text { sed }=11.8\left(Q_{\text {surf }} * q_{\text {peak }} * \text { area }_{h r u}\right)^{0.56} K_{U S L E} * C_{U S L E} \\
* P_{U S L E} * L S_{U S L E} * C F R G
\end{gathered}
$$

Where, " sed is the sediment yield on a given day (metric tons), $Q_{\text {surf }}$ is the surface runoff volume $\left(\mathrm{mm} \mathrm{H}_{2} \mathrm{O} / \mathrm{ha}\right)$, $q_{\text {peak }}$ is the peak runoff rate $\left(\mathrm{m}^{3} / \mathrm{s}\right)$, are $_{h r u}$ is the area of the HRU(ha), $K_{U S L E}$ is the USLE soil erodibility factor $\left(0.013\right.$ metric ton $\mathrm{m}^{2}$ ha $/\left(\mathrm{m}^{3}\right.$-metric ton $\left.\left.\mathrm{cm}\right)\right), C_{U S L E}$ is the USLE cover and management factor, $P_{U S L E}$ is the USLE support practice factor, $L S_{U S L E}$ is the USLE topographic factor and CFRG is the coarse fragment factor." Model set up and execution is done following the flow chart as shown in fig. 2 below.

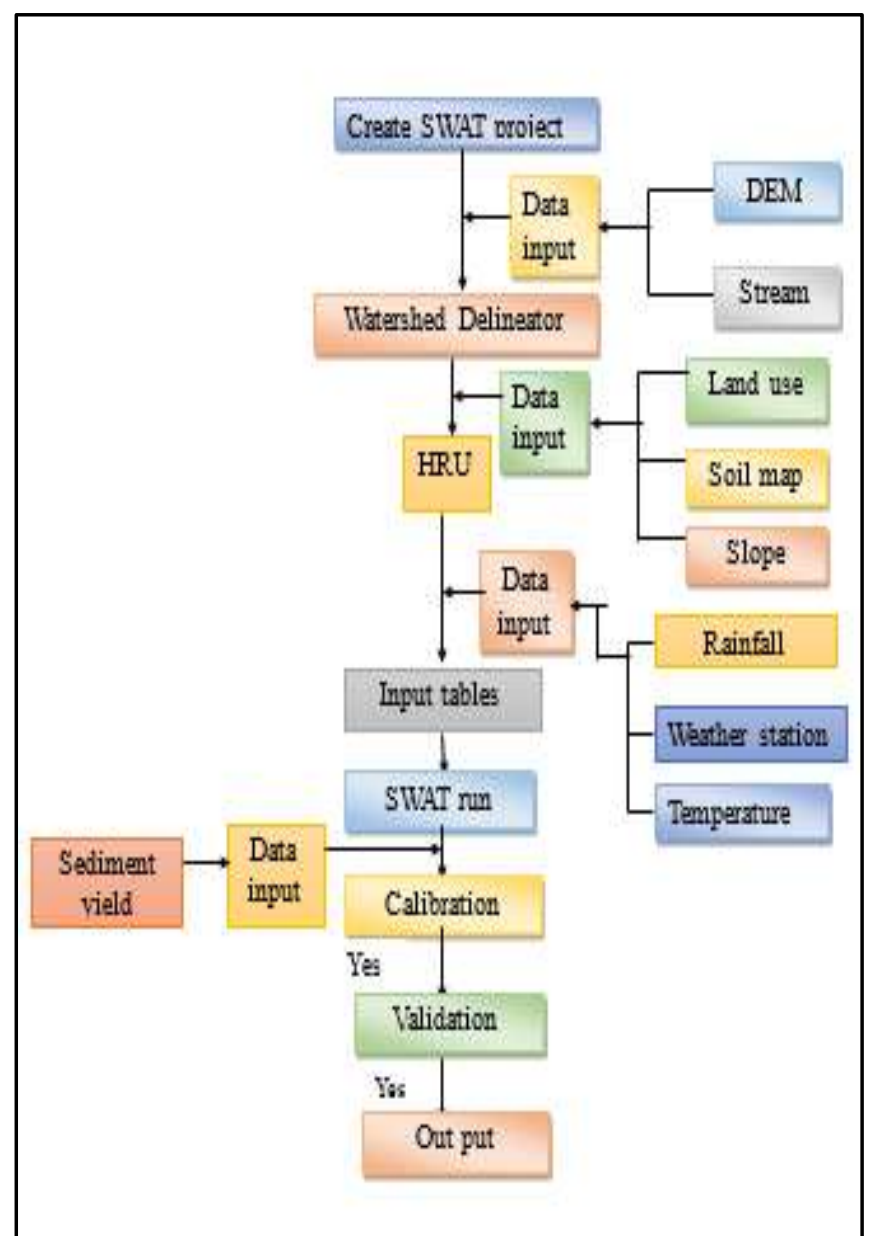

Fig. 2: Flowchartfor SWAT methodology

\section{RESULTS AND DISCUSSION}

\subsection{SWAT Calibration and Validation}

The calibration was done for the period 1981 to 1985 and was validated from 1986 to 1989 for sediment yield.Initially, before calibration, the observed values and simulated peaks values weren't matching with each other as shown in fig. 3. $\mathrm{R}^{2}$ and NSE values were found to be 0.4154 and 0.3217 respectively as shown in fig. 4 which represents the scatter plot for observed and simulated sediment yield for initial simulation. After performing number of trials, $\mathrm{R}^{2}$ and NSE values reached to desirable limits. 


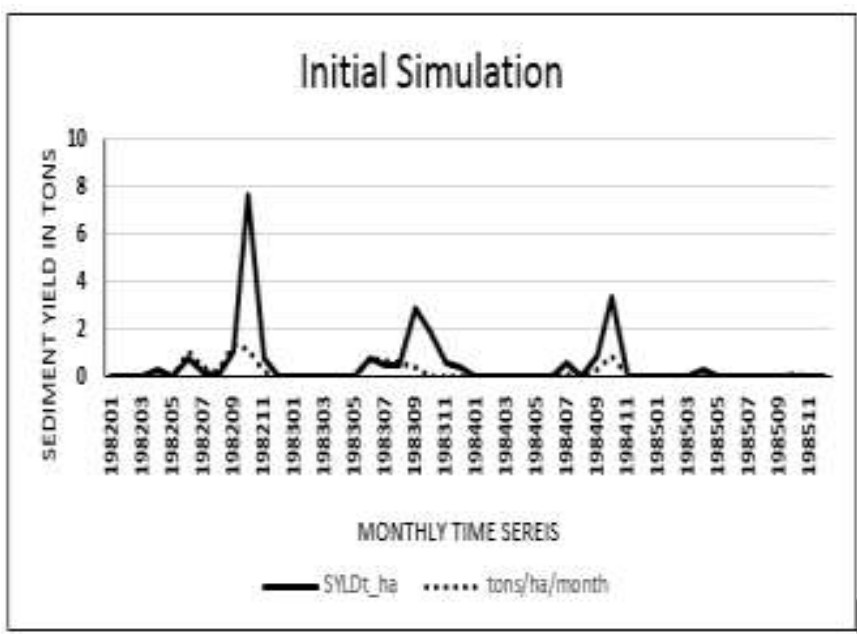

Fig.3: Average monthly observed and simulated sediment yield for the initial simulation

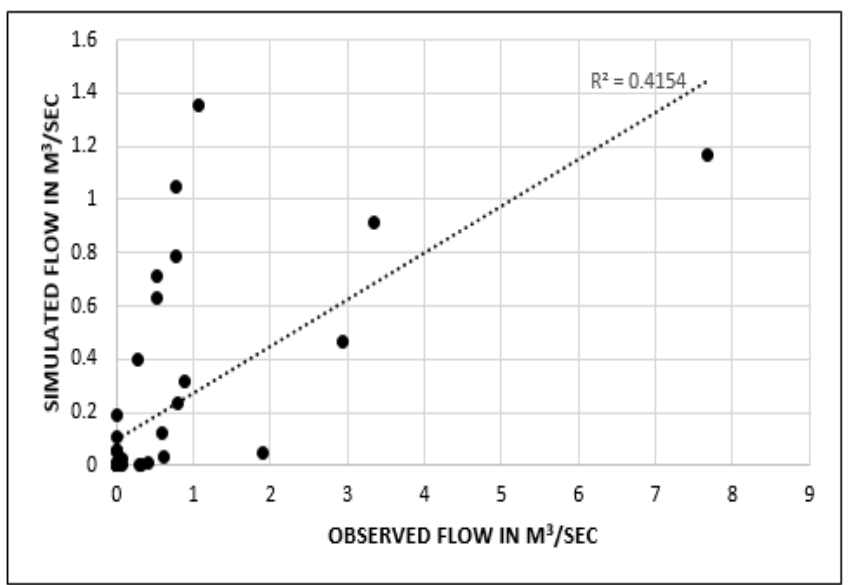

Fig. 4: Scattered plot for observed and simulated sediment yield for initial simulation

\section{CONCLUSION}

The model behaved well for the calibration and validation periods for both flow and sediment yield. The model performed fine for the model performance was found good for sediment yield evaluation with $\mathrm{NSE}=0.5216$ and $\mathrm{R}^{2}=0.6021$ for calibration period and $\mathrm{NSE}=0.6258$ and $\mathrm{R}^{2}=0.6997$ for validation period which were found within the acceptable range. It can be concluded that model performs good for the sediment yield evaluation.

\section{ACKNOWLEDGEMENT}

I would like to extend my sincere gratitude to my respectable supervisor Assoc. Prof. Dr. Nagraj S. Patil, Dept. of PG Studies, VTU Belagavi. Without his immense support, valuable suggestions and wise guidance it would not be possible for me to undertake this research work. His total commitment and involvement to discuss the problems has made this research a pleasure work. He has been a great mentor.

It is my privilege to thank my parents for their constant encouragement throughout my research period.

\section{REFERENCES}

[1] J. G. Arnold, D. N. Moriasi, P. W. Gassman, K.C. Abbaspour, M. J. White, R. Srinivasan, C. Santhi, R. D. Harmel, A. van Griensven, M. W. Van Liew, N. Kannan, M. K. Jha (2012). "SWAT: Model use, calibration, and validation." American Society ofAgricultural and Biological Engineers, ISSN 21510032 .

[2] Neitsch S. L., Arnold J. G., Kiniry J. R., Williams J. R. (2011). "Soil and Water Assessment ToolTheoretical Documentation, Version 2009, Texas Water Resources Institute.

[3] Prabhanjan E. P. Rao, and T. I. Eldho (2015). "Application of SWAT model and Geospatial Techniques for Sediment yield Modeling in Ungauged Watersheds." Journal of Hydrol. Eng. / (ASCE) HE, 20(6), pp. 1943-5584.

[4] Shimelis G. Setegn, Bijan Dargahi, Raghavan Srinivasan, and Assefa M. Melesse (2010). "Modeling of Sediment yield from Anjeni-Gauged Watershed, Ethiopia Using SWAT Model." Journal of the American Water Resources Association (JAWRA) 46(3), pp. 514-526.

[5] Moraisi D. N., Arnold J. G., Van Liew M. W., Bingner R. L., Harmel R. D., Veith T. L. (2007). "Model evaluation guidelines for systematic quantification of accuracy in watershed simulations." American Society of Agricultural and Biological Engineers 50(3), pp. 885900.

[6] Preksedis M. Ndomba, felix W. MTalo and AnundKillingtveit (2008). "A Guided SWAT Model Application on Sediment yield Modeling in PanganiRiver Basin." Journal of Urban and Environmental Engineering, Vol. 2, pp. 53-62.

[7] Sanjay K. Jain, JaivirTyagi, Vishal Singh (2010). "Simulation of Runoff and Sediment Yield for a Himalayan Watershed Using SWAT Model." Journal of Water Resource and Protection, Vol. 2, pp. 267-281. 